\title{
Effect of Training on Employee Performance: An Empirical Study on Telecommunication Industry in Bangladesh
}

\author{
JOBAYRA AFSANA* \\ FARHANA AFRIN ${ }^{* *}$ \\ TASNEEM TARANNUM ${ }^{* * *}$
}

\begin{abstract}
This research paper is an attempt to estimate the effect of training on employee performance in the telecommunication industry of Bangladesh. This study is conducted mainly based on primary data which were collected from a questionnaire survey encompassing the opinion of 100 employees working currently at six telecommunication companies. A theoretical framework has been formulated to estimate a relationship between training and employee performance, in the presence of intervening variables. Variables examined in this study are: Training (Independent Variable); Job Knowledge, Skill, Positive Attitude (Intervening Variables) and Employee Performance (Dependent Variable). The study revealed that there are positive and statistically significant effects of training on employee performance. The study also discovered that investment on employee training in the telecommunication sector can augment employee performance by enhancing job knowledge, skill and creating positive attitude among employees.
\end{abstract}

Key Words: Training, Employee Performance, Job Knowledge, Skill, Positive Attitudes, Regression Analysis.

\section{I.INTRODUCTION}

Bangladesh was the first South Asian country to adopt cellular technology back in 1993 by introducing Advanced Mobile Phone System. The mobile

\footnotetext{
* Lecturer in Management, Department of Business Administration, Northern University Bangladesh, Dhaka. E-mail: mim_ku03@yahoo.com.

** Lecturer in Management, Department of Business Administration, Northern University Bangladesh, Dhaka. E-mail: farhanaafrin19@gmail.com.

*** Senior Lecturer in Management, Department of Business Administration, Northern University Bangladesh, Dhaka. E-mail: tarannumjobs@yahoo.com.
} 
communications sector in Bangladesh is one of the fastest growing industries and has stimulated and aided the rapid economic and social growth in the country by generating employment opportunities by the firms in the telecommunications sector. It has also enhanced productivity in businesses as a result of easier exchange of information through mobile phone usage and creating a more conscious and knowledgeable employees, workforce and citizens. It has added a new level of comfort and convenience. This has become an indispensable service in the lives of general people of the country. According to the World Bank, an extra 10 mobile phones per 100 people in a typical developing country added 0.6 percentage points of growth in GDP per capita, and this impact is about twice as large in developing countries than in developed countries. Also in aggregate, including direct and indirect employment, more than 111,790 jobs have been created by the industry till date. (Ifty Islam, Deloitte, 2010, www.amtob.org.bd/re source/telecom-recommendation.pdf)

Employees are the most essential asset for any firm as they can extensively affect an organization's performance and profitability. Training is the process of improving the existing skills, knowledge, exposure, and abilities in an individual. It also enhances the capabilities of employees in a very effective way by motivating them and transforming them into well-organized and well-mannered personnel that ultimately affects the performance of organization. Without proper training employees' maximum capabilities remain under utilized. Laing (2009) defines training as an indicator of superior skills, knowledge, capabilities and outlook of the employees that result in effective performance of the workers. However, he adds one thing more that it (training) raises the production of the organization.

The aim of the study is to identify the impact of training on employee performance. In this article some intervening variables have been used to identify the extent of relationship between training and employee -performance.

\section{II.OBJECTIVES OF THE STUDY}

The main objective of this research is to identify the impact of training on employee performance. The specific objectives are-

- To investigate the impact of training on job-knowledge, skill, and employee- attitude towards job and organization.

- To examine the impact that job knowledge, skill, and attitude have on employee performance. 


\section{LITERATURE REVIEW}

Abdus Sattar Niazi (2011) in the article "Training and Development Strategy and its Role in Organizational Performance" has revealed that HR plays the role of establishing and implementing roadmap for strategic training and development. We know the strategic positioning of training and development directly promotes organizational business goals and objectives and thereby enhancing organizational performance. The research emphasizes that in the context of the developing countries, corporate universities provide a flexible framework within which training and development strategy is worked out to shape and implement a learning strategy that reflects the heart of the organization's learning culture, hence it positively contributes to the organizational performance.

Similarly Benedicta and Appiah (2010) mentioned a positive relationship between training and employee performance. Training generates benefits for the employee as well as the organization by positively influencing employee performance through the development of employee knowledge, skills, ability, competencies and behavior. Swart et al., (2005), mentione in his study that bridging the performance gap refers to implementing a relevant training intervention for the sake of developing particular skills and abilities of the workers and enhancing employee performance. He further elaborates the concept by stating that training facilitates organization in recognizing the areas where the workers are underperforming in terms of knowledge, skills and attitudes.

Wright and Geroy (2001) highlight that employee competencies can be upgraded through effective training programs. Comprehensive trainings enable employees to be flexible and adapt to future changes and demands required to give a superior performance on the job.

Afaq et al.(2011) in the article "Employees' Training and Performance Relationship in Hospitality Sector, A Case of Pearl Continental Hotel" identified that there is a significant relationship between the two variables; revealing that the employees who have taken trainings are more capable in performing different tasks and vice versa.

Afshan Sultana(2012) In the paper " Impact of Training on Employee Performance: A Study of Telecommunication Sector in Pakistan" observe that most organizations meet their needs for training in an ad-hoc and haphazard way while others set about identifying their training needs, then designing training activities in a rational manner and finally assessing the results of training. The study concludes that if organizations invest in the right type of employee training, it can enhance employee performance as well as competencies and skills. 
Falola et al. (2014) in the article "Effectiveness of Training and Development on Employees' Performance and Organization Competitiveness in the Nigerian Banking Industry" and Azara Shaheen (2013) in the article "Employees Training and Organizational Performance: Mediation by Employees Performance" have found that there is a strong relationship between training and development, employees' performance and competitive advantage. Khawaja Jehanzeb and Dr. Nadeem Ahmed Bashir (2013) in the paper "Training and Development Program and its Benefits to Employee and Organization: A Conceptual Study" find that employees are esteemed resource of the organization and success or failure of the organization rely on the performance of employees. Therefore, organizations are financing large amount on employee training and development programs. Muhammad Aslam Khan (2011) in the paper "Impact of Training and Development on Organizational Performance" have identifies that training and development, on the job training, training design and delivery style have significant affect on organizational performance and all these have positively affected the organizational performance. It means it increases the overall organizational performance. Rosenwald (2000) defined that providing employees training and development opportunities can be perceives a meaning that the organization cares for their employees. This perception in employees may produce benefits even though training and development structure and transfer might not be optimal.

\section{IV.RESEARCH METHODOLOGY}

This study is mainly based on primary data which have been collected from a questionnaire survey in March, 2015. A total of 120 questionnaires were distributed among the employees of six telecommunication companies and 100 questionnaires were returned back. The total response rate is $83.33 \%$. The questionnaire has been developed by using 5 point Likert-type scale consisting of assigned values between 1 to 5 where value $1=$ Strongly dissatisfied, $2=$ Dissatisfied, 3= Neutral, 4= Satisfied, 5= Strongly satisfied for the asked questions. Secondary data have been collected from articles of different journals, text books, websites, etc. Collected data have been analyzed through descriptive statistics (frequency and percentage) and regressions by using SPSS version 16.

The following theoretical framework has been formulated to draw a relationship between training and employee performance, in the presence of intervening variables. 
Variables examined in this study are:

- Independent Variable: Training

- Intervening Variables: Job Knowledge, Skill, Positive Attitude towards training

- Dependent Variable: Employee Performance

FIGURE 1: Relationship among training, employee performance and intervening variables (KSA-Knowledge, Skill and Attitudes)

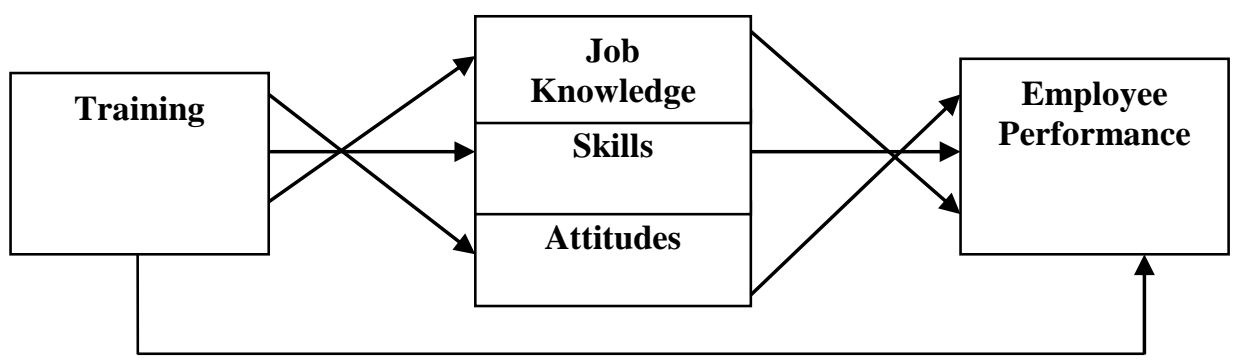

V. DATA ANALYSIS AND FINDINGS

TABLE 1

DESCRIPTIVE ANALYSIS

\begin{tabular}{lcccc}
\hline Gender & Percentage (\%) & Institution & Percentage (\%) \\
\hline Male & 57 & Grameen Phone & 18 \\
Female & 43 & Banglalink & 19 \\
Total & 100 & Teletalk & 17 \\
Work Experience in & Percentage $(\%)$ & Citycell & 16 \\
years & & & 13 \\
Less than 1 & 8 & Airtel & 17 \\
$1-3$ & 13 & Robi & 100 \\
$4-6$ & 34 & Total & Percentage (\%) \\
$7-10$ & 35 & Training Frequency & 16 \\
More than 10 & 10 & Monthly & 25 \\
Total & 100 & Quarterly & 52 \\
Income Level (Tk.) & Percentage & Annually & 100 \\
Less than 20000 & 22 & Others & \\
30000-40000 & 20 & Total & \\
More than 50000 & 9 & & \\
Confidential & 49 & & \\
Total & 100 & & \\
\hline Source: Fild Survey & & & \\
\hline
\end{tabular}

Source: Field Survey March 2015.

Table 1 reveales the personal profile of the respondents. This research took opinion from 100 respondents comprising of $57 \%$ male and $43 \%$ female. Most 
respondents i.e.35\% have work tenure of 7-10 years while only $8 \%$ of the respondents have less than 1 year of job experience. Employees with more than 30 years of experience constituted $10 \%$. About half of the respondents $(49 \%)$ are not willing to disclose their monthly income. Only $9 \%$ employees earn more than Tk. 50,000 monthly. From the 100 respondents 18\%, 19\%, 17\%, 16\%, 13\% and $17 \%$ employees work at Grameenphone, Banglalink, Teletalk, Citycell, Airtel, and Robi respectively. Of the respondents $16 \%$ employees get monthly training, $7 \%$ employees get quarterly training and $25 \%$ employees received annual training.

TABLE 2

\section{MODEL SUMMARY AND ANOVA}

\begin{tabular}{c|lcc}
\hline Hypothesis No. & \multicolumn{1}{c}{ Variables } & R Square & F \\
\hline H1 & Training \& Job Knowledge & .460 & 83.525 \\
H2 & Training \& Skill & .541 & 115.491 \\
H3 & Training \& Positive attitude & .349 & 52.560 \\
H4 & Job Knowledge \& Performance & .510 & 102.083 \\
H5 & Skill \& Performance & .354 & 53.788 \\
H6 & Positive attitude \& Performance & .416 & 69.857 \\
H7 & Training \& performance & .437 & 76.147 \\
\hline
\end{tabular}

Source: Field Survey March 2015.

Table 2 provides the result of value of coefficient of determination $\left(R^{2}\right)$ and F- test. The results of Model Summery and ANOVA test produced by the SPSS are reproduced in this table. $R^{2}$ explains the rate of the variation in the dependent variable is explained by the identified independent variable. F-test shows the total strength of the model (Andy Field, 2009). In case of hypothesis $1, R^{2}$ is 0.460 that explains training accounts $46 \%$ variation in job knowledge. The value of $F$ test shows that the model's strength is 83.525 . For hypothesis 2 , the value of $R^{2}$ is 0.541 which explains training brings $54.1 \%$ variation in skill. Here the model strength is 115.491 . The value of $R^{2}$ is 0.349 for hypothesis 3 that indicates $34.9 \%$ positive attitude is explained by training and this can be viewed that there might be other factors that bring variation of $65.1 \%$ in the outcome variable. Ftest shows that the model strength is 52.560 . In case of hypothesis $4, R^{2}$ is 0.510 that explains that job knowledge accounts $51 \%$ variation in employees' performance. The value of F-test shows that the model's strength is 102.083 . For hypothesis 5 , the value of $R^{2}$ is .354 which explains skill brings $35.4 \%$ variation 
in performance. Here the model strength is 53.788 . In case of hypothesis $6, R^{2}$ is 0.416 that explains that positive attitude accounts $41.6 \%$ variation in employees' performance. The value of F-test shows that the model's strength is 69.857 . The value of $R^{2}$ is 0.437 for hypothesis 7 with model strength 76.147 that indicates $43.7 \%$ variation in the employees' performance is explained by training. This can be viewed that there might be other factors that bring variation of $56.3 \%$ in the performance.

\section{Regression analysis}

All the hypotheses of the study have been tested by using statistical techniques through SPSS 16.0. Regression technique is used to test the hypotheses. B determines the value of the dependent variable if the independent variable is zero. $\beta$ explains the rate of change in dependent variable due to 1 unit change in independent variable .T-value shows that the regression model results as a good predictor of the dependent variable. P-value explains the significance of all the coefficients (Andy Field, 2009).

TABLE 3

IMPACT OF TRAINING ON EMPLOYEES' JOB KNOWLEDGE

\begin{tabular}{|c|c|c|c|c|c|}
\hline \multicolumn{6}{|c|}{ Coefficients $^{\mathrm{a}}$} \\
\hline \multirow[t]{2}{*}{ Model } & \multicolumn{2}{|c|}{$\begin{array}{l}\text { Unstandardized } \\
\text { Coefficients }\end{array}$} & $\begin{array}{l}\text { Standardized } \\
\text { Coefficients }\end{array}$ & \multirow[t]{2}{*}{$\mathrm{t}$} & \multirow[t]{2}{*}{ Sig. } \\
\hline & $\mathrm{B}$ & Std. Error & Beta & & \\
\hline 1 (Constant) & 2.400 & .245 & & 9.807 & .000 \\
\hline Training & 2.295 & .251 & .678 & 9.139 & .000 \\
\hline
\end{tabular}

a. Dependent Variable: Job knowledge

In table 3 , the regression analysis shows that, if emphasis on training is zero, job knowledge will be 2.295 and if training is increased by $1 \%$, job knowledge will increase by $67.8 \%(B=2.295, \beta=.678)$. The $\mathrm{t}$-value is 9.139 proving training as a good predictor of gaining more job knowledge.

Decision: The relationship between training and job knowledge is positive and statistically significant as the value of $p<.05$. So the null hypothesis is rejected. That means there is a statistically significant impact of training on employees' job knowledge. 
TABLE 4

IMPACT OF TRAINING ON EMPLOYEES' SKILLS

\begin{tabular}{|c|c|c|c|c|c|c|}
\hline \multicolumn{7}{|c|}{ Coefficients $^{\mathrm{a}}$} \\
\hline & \multirow[t]{2}{*}{ Model } & \multicolumn{2}{|c|}{ Unstandardized Coefficients } & \multirow{2}{*}{$\begin{array}{c}\begin{array}{c}\text { Standardized } \\
\text { Coefficients }\end{array} \\
\text { Beta }\end{array}$} & \multirow[t]{2}{*}{$\mathrm{t}$} & \multirow[t]{2}{*}{ Sig. } \\
\hline & & B & Std. Error & & & \\
\hline \multirow[t]{2}{*}{1} & (Constant) & 1.800 & .254 & & 7.088 & .000 \\
\hline & Training & 2.800 & .261 & .736 & 10.747 & .000 \\
\hline
\end{tabular}

In table 4 , it is shown that, if emphasis on training is zero, skill will be 2.8 and if training is increased by $1 \%$, skill will increase by $73.6 \%(B=2.8, \beta=.736)$. The t-value is 10.747 that represent training as a good predictor for measuring employees' skill.

Decision: The relationship between training and skill is positive and statistically significant as the value of $\mathrm{p}$ is .000 that is smaller than .05 . So the alternative hypothesis is accepted. That means there is a statistically significant impact of training on employees' skill.

TABLE 5

IMPACT OF TRAINING ON EMPLOYEES' POSITIVE ATTITUDES

\begin{tabular}{cc|c|c|c|c|c}
\hline \multicolumn{7}{c}{ Coefficients $^{\mathrm{a}}$} \\
\hline \multirow{2}{*}{ Model } & \multicolumn{2}{c}{$\begin{array}{c}\text { Unstandardized } \\
\text { Coefficients }\end{array}$} & $\begin{array}{c}\text { Standardized } \\
\text { Coefficients }\end{array}$ & $\mathrm{t}$ & \multirow{2}{*}{ Sig. } \\
& $\mathrm{B}$ & Std. Error & Beta & & \\
\hline \multirow{2}{*}{1} & (Constant) & 2.200 & .300 & & 7.333 & .000 \\
& Training & 2.232 & .308 & .591 & 7.250 & .000 \\
\hline
\end{tabular}

a. Dependent Variable: Positive attitude

The value of B is 2.232, indicates that if emphasis of training is zero, positive attitude of employees' will be 2.232 . The value of $\beta$ (.591) indicates that $1 \%$ change in training can change positive attitude up to $59.1 \%$. The t-value is 7.250 that represent training as a good predictor of employees' positive attitudes.

Decision: Here the null hypothesis is rejected as p-value is smaller than 05 . So there is a statistically significant impact of training on employees' positive attitudes. 
TABLE 6

IMPACT OF JOB KNOWLEDGE ON EMPLOYEES' PERFORMANCE

\begin{tabular}{|c|c|c|c|c|c|}
\hline \multicolumn{6}{|c|}{ Coefficients $^{\mathrm{a}}$} \\
\hline \multirow[t]{2}{*}{ Model } & \multicolumn{2}{|c|}{ Unstandardized Coefficients } & \multirow{2}{*}{$\begin{array}{c}\begin{array}{c}\text { Standardized } \\
\text { Coefficients }\end{array} \\
\text { Beta }\end{array}$} & \multirow[t]{2}{*}{$\mathrm{t}$} & \multirow[t]{2}{*}{ Sig. } \\
\hline & B & Std. Error & & & \\
\hline 1 (Constant) & \multicolumn{2}{|c|}{.727} & \multicolumn{2}{|c|}{1.996} & .049 \\
\hline Job knowledge & & .07 & .714 & 10.104 & .000 \\
\hline
\end{tabular}

From table 6 , it is found that the value of $B$ and $\beta$ is .793 and .714 respectively. This explains if emphasis on job knowledge is zero the performance will be .793 and if job knowledge is increased by $1 \%$, performance will increase by $71.4 \%$. The $\mathrm{t}$-value for this hypothesis is 10.104 therefore it can be concluded that job knowledge is an effective predictor of employees' performance.

Decision: The value of $\mathrm{p}$ is smaller than .05 which indicates that there is a statistically significant impact of job knowledge on employees' performance. That means the alternative hypothesis is accepted.

TABLE 7

IMPACT OF SKILLS ON EMPLOYEES' PERFORMANCE

\begin{tabular}{|c|c|c|c|c|c|c|}
\hline \multicolumn{7}{|c|}{ Coefficients $^{\mathrm{a}}$} \\
\hline \multirow[b]{2}{*}{ Model } & & \multicolumn{2}{|c|}{ Unstandardized Coefficients } & \multirow{2}{*}{$\begin{array}{c}\begin{array}{c}\text { Standardized } \\
\text { Coefficients }\end{array} \\
\text { Beta }\end{array}$} & \multirow[b]{2}{*}{$\mathrm{t}$} & \multirow[b]{2}{*}{ Sig. } \\
\hline & & $\mathrm{B}$ & Std. Error & & & \\
\hline \multirow[t]{2}{*}{1} & (Constant) & 1.740 & .363 & & 4.788 & .000 \\
\hline & Skills & .587 & .080 & .595 & 7.334 & .000 \\
\hline
\end{tabular}

The regression analysis shows that, if emphasis on skill is zero, performance will be .587 and if skill is increased by $1 \%$, performance will be increased by $59.5 \%(B=.587, \beta=.678)$. The $t$-value is 7.334 that indicate skill to be a good predictor of performance.

Decision: The relationship between skill and performance is positive and statistically significant as the value of $\mathrm{p}$ is $.000(\mathrm{p}<.05)$. So the null hypothesis is rejected. 
TABLE 8

IMPACT OF POSITIVE ATTITUDES ON EMPLOYEES' PERFORMANCE

\begin{tabular}{|c|c|c|c|c|c|c|}
\hline \multicolumn{7}{|c|}{ Coefficients $^{\mathrm{a}}$} \\
\hline & \multirow[t]{2}{*}{ Model } & \multicolumn{2}{|c|}{$\begin{array}{l}\text { Unstandardized } \\
\text { Coefficients }\end{array}$} & $\begin{array}{l}\text { Standardized } \\
\text { Coefficients }\end{array}$ & \multirow[t]{2}{*}{$\mathrm{t}$} & \multirow[t]{2}{*}{ Sig. } \\
\hline & & B & Std. Error & Beta & & \\
\hline \multirow[t]{2}{*}{1} & (Constant) & 1.5 & .33 & & 4.703 & .000 \\
\hline & Positive attitude & & .07 & 645 & 8.358 & .000 \\
\hline
\end{tabular}

The result of table 8 shows that, if emphasis on positive attitude is zero, performance will be .642 (B). If positive attitude is increased by $1 \%$, performance will increase up to $64.5 \%(\beta)$. The $t$-value is 8.358 that represents positive attitude is a good predictor of performance.

Decision: The p-value is smaller than .05 that indicates the null hypothesis is rejected. There is a statistically significant impact of positive attitude on employees' performance.

TABLE 9

IMPACT OF TRAINING ON EMPLOYEES' PERFORMANCE

\begin{tabular}{|c|c|c|c|c|c|c|}
\hline \multicolumn{7}{|c|}{ Coefficients $^{\mathrm{a}}$} \\
\hline & \multirow[t]{2}{*}{ Model } & \multicolumn{2}{|c|}{$\begin{array}{l}\text { Unstandardized } \\
\text { Coefficients }\end{array}$} & \multirow{2}{*}{$\begin{array}{c}\text { Standardized } \\
\text { Coefficients }\end{array}$} & \multirow[t]{2}{*}{$\mathrm{t}$} & \multirow[t]{2}{*}{ Sig. } \\
\hline & & B & Std. Error & & & \\
\hline \multirow[t]{2}{*}{1} & (Constant) & & .2 & & 7.208 & .000 \\
\hline & Training & & .2 & .661 & 8.726 & .001 \\
\hline
\end{tabular}

a. Dependent Variable: Employee Performance

The regression results show that the value of $\mathrm{B}$ is 2.484 explains that if emphasis on training is zero, performance will be 2.484 . The value of $\beta$ in the regression table 9 is .661 that indicates that if training is increased by $1 \%$, performance will increased by $66.1 \%$. The t-value is 8.726 that represents training is a good predictor of performance.

Decision: Here the null hypothesis is rejected and alternative hypothesis is accepted as the value of $p$ is .000 that is smaller than 0.5. That means there is statistically significant impact of training on employees' performance. 


\section{CONCLUSIONS}

Training presents a great opportunity to expand the knowledge of all employees. Training and development provides both the company as a whole and the individual employees with benefits that make the cost and time a worthwhile investment. The major objective of the study is to identify the impact of training on employee performance. To achieve this objective the study has used a theoretical framework with the help of three intervening variables (job knowledge, skills, and attitudes). The study revealed that there is a positive and statistically significant relationship between training and employee job knowledge, training and employee skills, training and employee attitudes, job knowledge and employee performance, skills and employee performance, and attitude and employee performance. From the analysis it is also found that, there is a statistically significant impact of training on overall performance of employees of the telecommunication industry in Bangladesh.

\section{RECOMMENDATIONS}

Training is a vital factor for improving the employee performance of an organization. So, organizations should invest generously on hands -on training program. In Bangladesh some employees of the telecommunication sectors don't even get any opportunities to attend any training program. So organizations should arrange proper training programs for the employees. Training needs should be timely assessed and there should be maximum similarity between the training environment and the work place environment. So the employees can avoid the reality shock. Training programs should be evaluated on a timely manner to ensure the effectiveness of any training program. If employee promotion and advancement are contingent on attending and participating at training programs, the acquisition of new skills and knowledge can be positively reinforced there by increasing the overall productivity of employees. Training also happens to be a great motivator for most employees. 


\section{REFERENCES}

Afaq, F. U., Yusoff, R. B. M., Khan, A., Azam, K., \& Thukiman, K. (2011). Employees' Training and Performance Relationship in Hospitality Sector: A Case of Pearl Continental Hotel, Karachi, Pakistan. International Review of Business Research Papers, 7(3), 149-158.

Andy Field. (2009). Discovering statistics using SPSS. Sage publications.

Benedicta Appiah April, (2010), "The impact of training on employee performance: A Case Study of HFC Bank (GHANA) Ltd”. Pp. 15-17.

Falola, H. O., Osibanjo, A. O., \& Ojo, I. S. (2014). Effectiveness of Training and Development on Employees' Performance and Organisation Competitiveness in the Nigerian Banking Industry. Bulletin of the Transilvania University of Braşov, 7(1), 161.

Guest, D. E. (1997). Human Resource Management and Performance: A Review and Research Agenda. International journal of human resource management, 8(3), 263-276.

Jehanzeb, K., \& Bashir, N. A. (2013). Training and Development Program and its Benefits to Employee and Organization: A Conceptual Study. European Journal of Business and Management, 5(2), 243-252.

Kothari, C. R. (2011). Research methodology: methods and techniques. New Age International.

Khan, R. A. G., Khan, F. A., \& Khan, M. A. (2011). Impact of Training and Development on Organizational Performance. Global Journal of Management and Business Research, 11(7).

Laing, I. F. (2009). The Impact of Training and Development on Work Performance and Productivity in Public Sectors Organizations: A Case Study of Ghana Ports and Garbous Authority. A Thesis Submitted to Institute of Distance Learning, Kwame Nkrumah University of Science, and Technology.

Niazi, B. R. A. S. (2011). Training and Development Strategy and Its Role in Organizational Performance. Journal of public Administration and Governance, 1(2), Pages-42.

Rosenwald, M. (2000). Working class: More Companies are Creating Corporate Universities to Help Employees Sharpen Skills and Learn New Ones. Boston Globe, H1.

Shaheen, A., Naqvi, S. M. H., \& Khan, M. A. (2013). Employees Training and Organizational Performance: Mediation by Employees Performance. 
Sultana, A., Irum, S., Ahmed, K., \& Mehmood, N. (2012). Impact of training on employee performance: a study of telecommunication sector in Pakistan. Interdisciplinary Journal of contemporary research in business, 4(6), 646-661.

Swart, J., Mann, C., Brown, S. and Price, A. (2005), Human Resource Development: Strategy and Tactics. Elsevier Butterworth-Heinemann Publications, Oxford.

Tiwari, U. The International Journal of Business \& Management. pp 1-13

Wright, P. and Geroy, D.G. (2001), "Changing the Mindset: the Training Myth and the Need for Word-class Performance", International Journal of Human Resource Management, Vol. 12 No. 4, pp. 586-600.

\section{APPENDIX}

Hypotheses developed in the study:

a) Hypothesis $H 1_{0}$ : There is no statistically significant impact of training on employees' job knowledge.

Hypothesis $H 1_{a}$ : There is a statistically significant impact of training on employees' job knowledge.

b) Hypothesis $H 2_{0}$ : There is no statistically significant impact of training on employees' skills.

Hypothesis $H 2_{a}$ : There is a statistically significant impact of training on employees' skills.

c) Hypothesis $H 3_{0}$ : There is no statistically significant impact of training on employees' positive attitudes.

Hypothesis $H 3_{\alpha}$ : There is a statistically significant impact of training on employees' positive attitudes.

d) Hypothesis $H 4_{0}$ : There is no statistically significant impact of job knowledge on employees' performance.

Hypothesis $H 4_{a}$ : There is a statistically significant impact of job knowledge on employees' performance.

e) Hypothesis $H 5_{0}$ : There is no statistically significant impact of skills on employees' performance.

Hypothesis $H 5_{a}$ : There is a statistically significant impact of skills on employees' performance. 
f) Hypothesis $H 6_{0}$ : There is no statistically significant impact of positive attitudes on employees' performance.

Hypothesis $H 6_{\alpha}$ : There is a statistically significant impact of positive attitudes on employees' performance.

g) Hypothesis $H 7_{0}$ : There is no statistically significant impact of training on employees' performance.

Hypothesis $H 7_{a}$ : There is a statistically significant impact of training on employees' performance.

For regressions the following model has been used: $y=B+\beta x$

Where, $y=$ dependent variable, $\mathrm{B}=$ constant, $\mathrm{x}=$ independent variable, and $\beta$ is the coefficient of the independent variable. 